\section{Broken images - "Auschwitz", nostalgia and modernity. The reception of the Holocaust in popular culture}

The title of this text names three aspects that define the frame of the reception of the Holocaust[1].

I am going to show the mechanisms of the influence of popular culture on the reception of the Shoah. This aim will be realized in a few main points[2]. There are some premises: that popular culture is a form of social, cultural and communicative system which consists of diverse other autoreferential and autopoietic subsystems. Autoreferential deals with the process of construction, sending and reconstructing of the systems of signs and the forms of perceiving of them. Autopoietic deals with the process of narration which does not depend only on the subjects (sender/receiver) but also on the mechanisms which are generally other than individual or collective forms of creation and recreation of the meanings.

In saying "popular culture" I mean "popular cultures" which meld with media of mass communication. Popular culture refers to the process by which the new forms of understanding of the axiological and social orders of values move fluidly from the very periphery towards the center of cultural discourses. This process determines and forms the evolution of knowledge and in this context also the levels of being, understanding and feeling.

In my title, firstly, the phrase "Broken images" implies that something was one (in the historical frame) but then became "broken", and that this is something which had referred to the source of the representation. Cognition in this context depends on the mediatization. Tim Cole wrote: "[...] tourists in Krakow, Poland, do not visit the ghetto area because that is where the Holocaust ghetto was located. Rather, they visit the ghetto area because that is where Spielberg filmed his movie"(Cole XII).

Now for the second part of my title: Auschwitz, nostalgia and modernity - these three categories shape our contemporary approximation of understanding. (I say "approximation", because it is hard to think and to use the word understanding without rejecting all of these interpretations which we can find bad). The word "Auschwitz" refers
Images

vol.VIII/no.15-16

Poznań 2011

ISSN 1731-450x

\title{
Introduction
}

\section{The contexts of the terms}

[1] The main thesis of this text were presented during the seminar at Ben-Gurion University in Beer Sheva (2010.06.17).
[2] I would like to thank Prof. Mark J. Webber for the linguistic revision and for professional guidance. 
to the form of treating Auschwitz as the historical, social and symbolic fact and as the metonymy and synecdoche of the all forms of the representations of the Holocaust in contemporary culture (it is interesting that this word is used also in the research as the metonymy for example in the Rosenberg and Milchman's book titled Experiments in Thinking the Holocaust: Auschwitz, Modernity and Philosophy, Agamben's book titled Remnants of Auschwitz: The Witness and the Archive).

The history of the International Monument (of the Victims of Auschwitz) represents how Auschwitz as the real place became also a domain of the reduction the memory about the Holocaust, how facts became a set of representations. In November 1958 during the press conference in the UNESCO building in Paris the decision of the jury of the International Competition for the monument to the victims in Auschwitz was announced. This jury, which was chaired by Henry Moore, nominated the project of Polish artists run by Oskar Hansen, called The Monument-Way (Gutt: 1959, 18-19, quoted by Piotrowski 125).

In 1962 Pietro Cascelle's project (he cooperated with Jerzy Jarnuszkiewicz and Julian Pałka and with Italian architect Giorgio Simoncini) was begun. This project was realized in 1967 on the terrain of Auschwitz-Birkenau.

Comparing both of these projects provokes a question about the limits of the representation of the Holocaust and about the possibility of the creation of the meanings which can reveal the scale and character of the Nazi crime. (Piotrowski 125).

From the beginning of the thinking about the function of memory in Auschwitz, the problem of irrepresentability of the Holocaust was very important. In the context of Auschwitz as the historical, social and symbolical fact two difficulties in the representation of the genocide were important: the narrative vacuum on the one hand, and on the other hand the negation of the narrative frames. First perspective is impossible to imagine in the context of the Holocaust because there was no normal experience which could be taken in the process of narration, which could create the continuity of some event from the past to the future in the context of this FACT. The normal experience, as Piotrowski says, has the tradition of some narrative structures, the sequences which are experienced and can be foreseen in some frames. The Holocaust in this context is a kind of narrative vacuum (Piotrowski 126). The second problem concerns the inadequacy of these narrative frames to the trauma. Both of these problems are one in the context of the question: how to represent the traumatic experiences of Auschwitz?

The project of the Monument-Way was something different than the Monument of the Victims of Fascism. Piotrowski wrote that Monument-Way showed that the empathy of the visitor/sightseer with the victim is impossible, that it is impossible to immerse oneself in the 
experience of the people who were killed there or lived there. This Monument-Way - which was a path (way) through Auschwitz without any possibility of coming into the space of the actual death camp - was not only a form of thinking about memory but also a form of critical thinking about the possibility of "visiting" Auschwitz, where the conception of camp as the museum or almost something like a heritage park abused the past of this place (Piotrowski 129). Restoring this camp after 1945 was in this context a form of ideology (to create a "myth" of Auschwitz) (as the reality of the industry of killing). Hansen's project was an opened form, a kind of anti-monument which maintained silence in the context of the death of so many human beings. The Monument-Way could not permit people "become accustomed" to this death camp. In this context, memory was not mediated by ideology, politics, teachers or tourist guides - it became the possibility of internal, intimate memory outside of any form of the official narration and outside of any official pattern of approximation. The Monument-Way was like an infected wound, preserving memory in a form of neurosis (Piotrowski 129, 130).

Hansen's project wanted to stop the process of replacing death and genocide by myth. We can say that Auschwitz in this connection is like a metaphor what remains incomplete. In metaphor theory one can speak of two parts of the metaphorical process, in that a metaphor consists of that which does the signifying (the significant) and that which is thereby signified (the signifié).

Auschwitz is a kind of signifiant without a signifié because of the narrative vacuum I have described. In this context Auschwitz was also the recipient of different forms of signifié, becoming a sign which can attains meaning by the interactions with these signifiés and with other signifiant that can be substituted by it. A meaning of Auschwitz as the metonymy of the Holocaust depends on the interaction with other signifiants which refer to this genocide, what is visible in the context of the movie. The mythologization of Auschwitz means that Auschwitz can be a potential sign understood in the context of interaction with some other signifiés (the pattern of word, either in mental or ideological projection), for example determined by ideology, policy or historical policy: that is why it is possible for some people to think about the holocaust of animals, AIDS as mass murder, or about inviting prisoners to Auschwitz to show them what does the death of innocent people mean. The context of movie refers to other problem - that signifiant can be a sign by the superiority of the other signifiant (when popularity of some text means "real" and "prevailing"): for example the comparisons of the film Schindler's List with Life Is Beautiful (1997) or with The Pianist (2002). The truth of the Holocaust is the "one truth" in this context because there are other "truths" shown in other films. This perspective is important in the perception, but it reveals the reduction, breaking the images of this genocide. 
The mythologization of Auschwitz is well seen in the context of tourism which uses the narrative tools typical of popular culture in reflecting the mechanisms of the reduction of the Holocaust. Julian Kornhauser wrote in his poem titled Origami: "On the train from Cracow to Auschwitz / The three young Japanese / are folding origami / killing the time./ We go past hills and forests, / and a paper / swan sleepily glances at the blazing / grass." (Kornhauser 53, trans. by M.K.) In this context Auschwitz is a place, next place worth of seeing, visiting, just for "killing the time". It is a form of "performing the memory" when some visitors try to imitate behaviors of the other visitors to show that their visiting in this place is not a mistake, not accidental. The limits of language reveal death present in the metaphors: Auschwitz becomes an image of "Auschwitz", like "killing the time" becomes only an image of boredom. "Japanese" is a figure of tourist who can be interested only in the surface of the facts.

The images in visitors minds are shaped by the palimpsests which consist of (maybe) some photos taken in the historical Auschwitz and the other places of genocide and pictures which a visitor does remember from the movie (or other forms of popular narrations). (A seller from the shop with the souvenirs in Auschwitz remembered as she listened to some people who bought colorful candles as the gifts) [3].

Remembering in this context is a form of remembering of some broken images which can be the source of nostalgia. Regarding the influence of popular culture on the reception of the Holocaust, Ankersmit is partly wrong is saying that nostalgia creates the bridges between reality and the truth of emotions and feelings. The nostalgia, as the strongest form of memory (it is Ankersmit's theory), reveals that it is impossible to cross the distance which divides people from the contents of their nostalgic memory (Ankersmit 405). What I am going to say is that nowadays nostalgia is mediatized, is rather a form of a simulated set of broken images than looking for the past about which Ankersmit wrote. Nostalgia - in the Greek language - comes about when two feelings are simultaneously sustained: the desire to come back home nostos and the feeling of pain - algia (Ziębińska-Witek 9). Here, however, home is rather a form of time than a space. Nostalgia in the context of the influence of popular culture is a form of "homecoming" to another image.

The word nostalgia has an ambivalent meaning which mixes the perspective of those people who know that it is important to remember and on the other hand these who think that it should be remembered, so the word "nostalgia" determines two aspects - epistemological and moral, but because of the influence of popular culture these aspects are suspended by their substitutes - moral by aesthetic (Mintz, describing the changes in understanding the Holocaust wrote:

[3] The source of this information comes from "Polityka". E. Gietka Jak opowiedzieć Auschwitz.
Głosy, “Polityka”, 5(2010). 
"While the earlier debate focused on issues of passivity and self-defense, this later one shifted the discussion to the problems of the aesthetic representation of the Holocaust and the capacity of popular media such as television to treat the event without trivializing it"; Mintz 24)

and epistemological by the ideological (for example Novick wrote: "[...] the Holocaust was still being recycled for cold war purposes [...]"; Novick 127). Nostalgia concentrates on the differences and distance between past and present, although the past is totally lost even when it is misunderstood as being present through its representations (Ziębińska-Witek 9, 10).

Modernity in this context does not designate a period of civilization but rather a form of confrontation of subjectivity with technology where some aspects of humanity are realized by the technological possibilities, where technology becomes the "body of death". Mass media are the tools which still represent the continuity of modernity, also in its radical way. Modernity on the level of using technology never stopped developing. Modernity by the social implosion of the technology became a transparent form of using without necessarily adding the prefix "over-", to result in overusing. Modernity did not end when World War II had finished; in fact, it strengthened - in the wake of WW II, as the cybernetic discourse and collaborative work styles of cold war military research came together. We remember mainly about the synchronic answer of the mass killing and destruction understood when it came with the communitarian social vision of the counterculture (Turner 9).

Modernity focuses on technology and death which are both against life, though they are pro biopolitical patterns of social and cultural discourses of inclusion and exclusion: Marcuse stated that the fight for life, and the fight for Eros are nowadays a political fights (Marcuse was in this context before Foucault and Agamben) (Marcuse 22). Metaphorically we can say that the source of modernity are in the Manichaean division of the world along the two systems of values: good and bad, white and black - and modernity will exist till the time when this model of understanding the discourses of otherness would divide the world. The cold war depended not on the "temperature" but on the indirect relations of perpetrators, spectators and victims. The myth of dehumanized technology is a metaphysical interpretation which treats humanity as a fairy tale. Vattimo showed that technology has the power of new experience of humankind (Vattimo 22).

The phrase "Broken images of the Holocaust" refers to the fact that the truth of the Holocaust is reduced to the confrontation of some, sometimes nihilistic, forms or sets of equivalences. The arbitrary of choice is instead of knowledge - and it is one of the main results of the reception the genocide in popular culture where modernity and nostalgia make Auschwitz the source of broken images. In this context Inglorious Bastards (Tarantino: 2009) can be a funny movie which is only a game and provokes us, earning money in 
a fashionable style. The narration is only a game. The question is: with whom?

And last but not least - the reception of the Holocaust in popular culture means that the reception reveals a way of cognition determined by the reduction and mediation of some texts as the sources of memory and knowledge.

The main hypothesis of this text is: The mechanisms which are typical for popular culture determine the ways of the reception of the Holocaust which means that popular culture models the ways of representation and approximation of the understanding of this genocide. Therefore the strategies, also individual, of approximation of understanding of the Holocaust are shaped by the frames of representation reflecting the dominant media of discourse (for example films, novels, TV shows).

Popular culture is defined by the mechanisms: of standardization, repetition, unification, mediatization and substitution through analogy (Kloch 2006).

Standardization means the reduction to average knowledge, average competences, average understanding. It is a problem when we think about the word "average" because this word implies for example a modeled receiver who is treated as a real. Instead of high culture in popular culture we can think about differentiation; instead of mass culture we can think about standardization. Repetition means that something that is known should be well known and something that is unknown - if it is not interesting enough - should be omitted (forgotten). Repetition concerns the forms of messages, the styles of talking, the forms of narration and representation: love, death, heroes, cruelty, fear etc., almost literally. Repetition is a form of explaining something by the same thing (idem per idem). Because of the influence of mass media - mediatization - the processes of standardization and repetition make the cultural texts, representations, pleasant and easy to perceive. Unification in this context means that the order of values in the fictional worlds are given like a pulp (it means that a "new" cultural text consists of the former, well known signs, forms of narration and similar styles of representation) which should be only accepted by the receivers. Unification is modeled by the colloquial language, simplification and common sense without a necessity of knowledge. In this context the mechanism of substitution by analogy reflects the general mechanisms of signs functioning in a "deformed way" (for example the VW factory near Poznań was called "Auschwitz" by some citizens in the bus [the author of this text listened to them]). "Something" can exist as "everything" if we think that the aesthetic level represents the same scale of values and knowledge as the level of cognition. A mistake is not a mistake, it is a fact which can be historical, functional or symbolical and which can become real because of the social interactions (we would like to say: a series of misunderstandings, deforma- 
tions; a radical example of the overusing the Holocaust by the social interactions is the convention Nazi exploitation; Luther-Smith: 1970, 39, quoted by Petley 10).

To sum up in the context of all of these mechanisms, a good receiver means a passive receiver who is ignorant. Broken images in this context can be treated as the representations that undergo the power of general reification where almost everything can be reduced to exchangeable values. In this context, the Holocaust became a story (fairy tale) (Vattimo 23). It is good to watch pleasant films; it is bad to know to which reality they refer.

"Schindler's List shows us the exceptional story of 1,100 Polish Jews who were saved, rather than killed, during the Holocaust. Life Is Beautiful shows us the exceptional story of a boy who survived a concentration camp, rather than being killed. Jakob the Liar shows us the exceptional story of a ghetto that was liberated, rather than liquidated. Train of Life shows us the exceptional story of a 'deportation' train that took Jews to freedom, rather than to a death camp. All in their own way skirt the horrors of the Holocaust and offer us something much more palatable in its place $[. .$.$] The massage is essentially the same. We can, through cunning,$ goodness and ingenuity, defeat the Holocaust and bring about salvation" (Cole XVII).

The "exchangeable" values are the consequences of modernity when a man became "expendable" (Rubenstein 10).

These mechanisms erase the differences between the official and individual discourses, between the cultural periphery and the centre. The strong influence of these mechanisms creates the conviction that the Holocaust happened in the far, far, "far-gotten" past and is real only in the fictional worlds. It is important that the average receiver can tell that the film Schindler's List concerns the Holocaust but this same receiver often forgets that the Holocaust was in a real, "not shown and not watched" space which is closer to his/her daily life (some places, where Jews were killed, are "forgotten" "erased", many of them are parks, etc.). The museums which are important in creating the historical, social and symbolical knowledge very often become the places which remember themselves. The same or almost similar problem concerns the films and TV programs - these texts become only a part of something. And finally the Internet in this context repeats the same problems - the knowledge about the Holocaust becomes the intimate set of data remembered by itself.

Broken images mean that every of the form of narration about the Holocaust is like an idiomatic discourse, almost autistic source of signs. You can disagree with this interpretation, but before saying "I do not agree", it is good to think about the lack of consequent, cohesive and critical thinking in the context of mass presented messages concerning the genocide. The problem does not concern the necessity of the big one (one-dimensional) narration, or the centre of discourses about the Holocaust but the subjectivity which is still the same, almost 
indifferent during watching films about the genocide looking there for some love story episodes or who during watching TV could think that killing people is only a mask, a show important in covering the daily routine life. Modernity in this interpretation becomes only much more radical, but still a useful and pleasant source of affirmation life by the negation of it, by suspending life's multidimensional.

Talking about the mechanisms of popular culture it is good to remind ourselves of the division proposed by Michel de Certeau: The mass sender creates strategies - in this context we can talk about official discourses, but the individual receiver creating some tactics uses only some fragmented, broken images taken from these official narrations creating individual, non-official tactics of understanding. Broken images are the content of the schizoid identity where consistent thinking is not important and not useful (de Certeau 37).

The paradox is that some people who, for example walk in the park (their daily life, daily tactic of being), do not know or do not remember or just are indifferent that they are still in the place where the Holocaust was not an image, but a fact, that the path in park goes through the Jewish cemetery. It is not a palimpsest; it is a result of ignorance. In popular culture this ignorance is the way of thinking. That is why for example during watching TV news we observe that some people as the authorities define us or explain us something what should be or might be treated as a simple and understandable problem which can be solved without any efforts.

\footnotetext{
"There is also an independently dangerous media effect, dangerous not because it is in the service of a specific ideology but because it surrounds us with invasive simulacra of time present, especially real-time news. These immediacies demand consent to worldliness for which there seems to be no alternative. It is as if time itself had become a commodity in Marx's sense, an abstraction with a fetishized and spooky life" (Hartman 102).
}

The perception is not a palimpsest because some continuity in thinking was broken. The same people who walk through the park can be empathetic when they think about the Holocaust watching Schindler's List. They are able to think that the Holocaust happened somewhere and "once upon a time", not relating this intuition (let's say: knowledge) with the history of the genocide in their town or village or forest.

It is also interesting how many death camps people can indicate, in comparison to the number of films about the Holocaust which they can mention. It is not a "palimpsest", it is not even knowledge, it is rather the result of the forms of narration typical for contemporary, stimulated and simulated images of memory performed according to the mass media patterns. Popular culture helps in constructing the poli-narrative (non-logical) identities which do not have to be complementary. I can learn about the Holocaust, I can watch films about it, but it is not the same that I can understand that it was a part of the history of my village, my town or my society. 
The strategies of creation, sending and receiving the cultural texts are shaped not only by ethical, epistemological or ideological causes but also by the economical aspects of popular culture. The representation of the Holocaust - does not suffice, it must be supported by the mechanisms of selling the product. As an example of this situation we can say about the posters of the film titled The Courageous Heart of Irena Sendler. "How did one woman save 2500 children? Unforgettable. Inspiring. True" (English version) and "... she rescued two times more people than Oskar Schindler" (Polish version) - both of them mean "worth of watching", spectacular; both of them reduce the fact to the commodity which must be sold successfully.

Thinking about these posters which are a comparison of the scale of genocide hidden by the comparing the scale of help as a cause because of which some film is worth of watching, we can observe how instrumentalized is the fact of death, as if the reception of the Holocaust was the problem of choosing among numbers. The reception of this genocide is shaped by the styles of narration which are typical for almost every form of selling products which must be sold. The reception is in this context determined by the industry of selling, which means that the system of values relates to the system of economical equivalents (Cole 1). The mechanism of promotion is not indifferent in terms of axiology - it shapes the horizon of values where the quantity (of rescued victims, killed people must be find an equivalence in the numbers of spectators, users of product - it is a bitter truth but unfortunately Frankfurt school was right saying about the cultural industry) define for example the dimension of human sacrifice. The sense of watching seems to be "the performing of empathy".

There are some advantages and disadvantages of popular culture. In the context of the reception of the genocide in popular culture this division is almost similar. People can find out something about this genocide (this finding out is something positive), but they can develop knowledge which is full of mistakes, which is a result of ignorance. People who are manipulated seem to be free, but the price of their freedom is their ignorance and decline of their critical thinking. Although it makes them feel secure. They themselves accepted heteronomy also in the context of interpretation of the past without deep diverse knowledge (Marcuse 6). The reception of the Holocaust in mass media is determined by the financial frames of the influence, which means that the styles of narration must be adequate to the demands of the free market (Cole 11) therefore some images of the Holocaust become in the process of reception the source of possible, for example, sentimental (or love) stories with a happy end.

This argument is ambivalent also because the tourism industry functions at the same level. In this context it is possible to be able to agree with the hypothesis that the reception of the Holocaust is synonymous with the reception of the controlled ignorance. It refers to the idea that everything can be "everything" in the context of the prin- 
ciple (typical for the popular culture): if something is good, more is better (Weizenbaum 27). Popular culture is a system of possible and autopoietic substitutions: nostalgia instead of knowledge, visiting instead of exploring, watching instead of thinking, beauty instead of death, Eros instead of death, mythologization instead of interest and silence, analogy instead of discourse, sentiments instead of discussion, demagogy instead of dialogue, present instead of past and future. Because of the influence of the economy on the reception of the Holocaust, where mass media are the example of this issue, the Western societies transformed radically. Thinking about the Holocaust is passé because there are some other important and actual problems. It does not mean that contemporary society knows more or understood more, no it is possible to state this sentence only because of the ignorance. Western culture did not work enough about this issue to leave it in the data of museums, in the Internet or to the disposition of the directors of films. It is truth that there are some other issues: every country has own problems, pain etc., although the Holocaust is still the darkness core of identity for the Western civilization which must be taught without prejudices.

This economical influence determines the social status of the forms of remembering and forgetting some aspects of the Holocaust. The economical influence becomes very often the source of the "dialectic of forgetting" (burying or suspending of some facts) and giving the "proper" (social result of acceptation) form of understanding and defining the problem. It makes - in a social way - the "real" meaning of fact. It is not true that we can only observe the selling of products but also by this selling we can observe the ways of creating some facts as the only ones, as the really important ones. It is selling the ways of remembering and forgetting, the ways of knowing and the ways of ignoring, or like Cole even suggests: "swallowing a sugar-coated 'Holocaust" (Cole XVIII). It makes that something becomes important not only because of the referring to the history, but by relating to the stories which define the limits of the significance of it in the social contexts of reality.

Almost everything that popular culture does with representations of the Holocaust is, in my opinion, common for all of these levels of the approximation to the limits of representation of humanity. The frames of imagination of the Holocaust during the process of reception become the limits of the representation of humanity in the Western culture. This hypothesis concerns the anthropological, social, cultural, historical, psychological and political aspects of humanity. Maybe the main gift received by Western culture from romanticism is a nihilistic and sentimental conception of something that should be sufficiently "interested". It means that sadness created a human as a much more interesting being, because in romanticism being sad meant being sophisticated and sensitive, and in the other context being powerless in confrontation with the fortune. According to this 
statement it is obvious that popular culture as a performance of romanticism in the one-dimensional frames of narration focuses on the being sad as a being interesting, even when activity must be sad and powerless in confrontation with the figures of fortunes.

This aspect can find its own realization as a form of reduction of the Holocaust in popular culture (Sontag 35, Struk 35). Something that should be shown as a sufficiently interesting in popular culture is also a substitute of political choice. Crying during watching films, where Jews are being killed, is a sentimental form of nostalgia, but when contemporary Jews put up a fight, it is not interesting because their "cultural way" was perceived to be interesting by virtue of their sadness, not of their glory. It is an example where the aesthetical frames define the political equivalents of the perception of some facts. Generally nowadays a spectator - sitting in front of his TV or in front of the interface of some website - is the user of technology, policy, ethics or love. It makes her/his choice as a socially multidimensional act of acceptation of some values by rejecting the others. A similar perspective was foreseen by Leon A. Jick who wrote that

"Some serious scholars question the focus on the Holocaust to the exclusion of other aspects of the Jewish past and present. They point out that fully one half of the scores of colleges and universities (this text was written on 1981) which now offer a course on the Holocaust, teach no other classes on Jewish history and culture. Students taking such courses are often unaware of what preceded or followed the catastrophe or of what was destroyed. Their knowledge of the Jewish experience is limited to victimization - how Jews died" (Jick 316) [4].

If we would like to agree with the conviction that romanticism gave this form of understanding of something because it was interesting, so the popular culture threw this "being interesting" into the political frame.

The limits of humanity do not mean the limits of language but the horizons of the representation Eros and Thanatos in culture (it is How instrumentally a special problem which concerns the status of euphemisms in popular culture which are used as result of the totalitarian power to reduction by the system of signs the social interactions among people. At this level popular culture also sustained some radicalized aspects of modernity). Howard Jacobson's Kalooki nights showed how contemporary culture abused the naked bodies of victims and the Nazi uniforms - and in this context how instrumentally we can treat death and life.

Sadomasochists' uniforms refer to the Nazi uniforms (for example Guido Crepax's comic books from the 60s or "Stalags"). "Stalags" (in Deutsch: "POW camp") were pocket books whose stories

[4] L.A. Jick, The Holocaust: Its Use and Abuse within the American Public, [in:] "Yad Vashem Studies", no. 14, Jerusalem 1981, p. 316. 
revealed lusty female SS officers sexually abusing camp prisoners. During the 1960s, parallel to the Eichmann trial, sales of this pornographic literature broke all records in Israel as hundreds of thousands of copies were sold at kiosks[5].

The narrator of the film titled Holocaust and Pornography in Israel related that the "Stalags" were one of the first sources of knowledge about the Holocaust ( $37 \mathrm{~min}$. of this film) - and in the context of the social influence of this film this information functions as a fact which must shape our understanding of the reception of the genocide in contemporary culture. Comparing this thesis with information published by Segev we can understand how spectacular it might be for the public opinion. It is misunderstanding when the receiver of this film would think that after reading "Stalags" people were able to know more about the Holocaust. Confronting the thesis from the film with Segev's description we can understand that the "Stalags" were read when people in Israel knew a lot about the Holocaust, although Eichmann's trial opened the public discussions which were focused on this genocide. The author of The Seventh Million wrote:

"Toward the end of November 1942, the Jewish Agency executive made an official statement asserting that the murders were being carried out in accordance with a master plan to exterminate European Jewry and that a special state apparatus had been established for that purpose. «Multitudes of children up to twelve years of age have been killed with no mercy, and the elderly have been killed as well,» the agency stated, adding that masses of people were also sent off to unknown destinations and all trace of them was lost [...] On the eve of the war, close to half million Jews lived in Palestine. Two out of three had arrived during the preceding decade; one out of every five had been in country five years or less. The vast majority had come from central or eastern Europe. Many, perhaps most, had not yet broken their ties with their places of birth. To these immigrants, the cities and towns conquered by the Germans were not just names in the news, and the death camps were not distant planets. They received reports of friends and relatives who had been deported, lost, or killed - fathers and sisters, husbands, wives, and children. The Holocaust was their personal tragedy; they lived in fear, in mourning" (Segev 74, 77).

"Stalags" became a space of "loosening" the relations between signs and their designations, what made the instrumentalization of the past possible and real. The overestimation of the influence of this kind of pocket books is a kind of recreation the knowledge about the past by the broken images.

The popularity of "Stalags" is relevant to the trial of Eichmann (30:55 min:s.). The film Holocaust and Pornography in Israel posits that pornographic images appears in canonic Holocaust literature and continue to be spread as part of the representation of the Holocaust in

[5] Holocaust and Pornography in Israel. Documen-

tary. Israel 2007, by Ari Libsker, www.stalags.com

(2010.04.11) 
Israel, in schools, books (remarks about K. Zetnik The Doll House) and trips to Auschwitz.

Regarding all of these contexts there is a concerning hypothesis: the problems of telling about the Holocaust became the source of the overusing the fact of its having occurred - it is hard to talk using knowledge, so in a very short time this FACT became the source of abuses, like other forms of taboo in culture, also like death. Geoffrey Gorer wrote about "pornography of death" describing the situation where the death became in public life a form of excluded taboo about which people started talking only like about the sexuality - in a very radical, reduced way, very often they did not know generally what they should to say, because there was also a lack of language. People avoided the subject of death, or by the analogy to sexual taboo - they talked about it either instrumentally or ironically. The broken images of the Holocaust reveal this genocide as the form of cultural taboo. Paradoxically the reduction of the knowledge and memory about the Holocaust to the "melted" frames of Eros and Thanatos showed how this genocide became a "controlled taboo" (which can be treated instrumentally because of the diversity of the styles of thinking and proportional to them levels of ignorance, this intellectual form of indifference).

"Between sado-masochism and fascism there is a natural link. «Fascism is theatre», as Genet said. As is sado-masochistic sexuality: to be involved in sado-masochism is to take part in a sexual theatre, a staging of sexuality. Regulars of sado-masochistic sex are expert costumers and choreographers as well as performers, in a drama that is all the more exciting because it is forbidden to ordinary people" (Sontag: 1981, 103, quoted by Petley 13).

Such cruel women like Ilse Koch or Irma Grese[6] were the source of distasteful inspirations for many representations of sexual abuses. Body became the medium of the message - if you need me, you must harm me. The taboo of sexual confrontation was melted with the representations of the Holocaust. The film titled The Reader which became very popular, and was inspired by Schlink's novel of the same name, was described in a Polish review as a romance between a young boy and an older lady who was during the war a guard in the death camp. I have not read any text where was even a small note that this film, inspired by novel, was the voice of German second generation after the Second World War about their law of living in history and about the role, mainly intellectuals during the Nazi period.

Thinking intertextually we can say that the novel, titled The Reader, and the film, were rather a form of question why "the angels fell in Berlin". Regarding all of these complex contexts it is possible to assume that The Reader was popular because, as one character from 
the film about "Stalags" said (thinking about this kind of pocket books), the spectators (as the receivers) could make love with the Nazi guard. This interpretation has a long tradition in popular culture: it is a tradition of "Stalags", the comics strips created by Crepax, "series novels such as Gretchen en uniforme and Gretchen sans uniforme, which were little more than pretexts for scenes of sex and violence against a Nazi backdrop" (Petley 12) or then Ilsa, She Wolf of the SS (1974, directed by D. Edwards) or magazine like Real Men (USA 1961). Via the erotic or even pornographic images the reception of the Holocaust started surrendering the frames of narrations which are typical for popular culture. For some scholars it is a result of the changes at the map of generations: the same contents for the first generation now became a matter of aesthetical taste, as if the understanding of the Holocaust was only still the signifiant which looks for the next signifié [7] (depended on the social and the ideological trends) to be able to be understandable. The Holocaust does not depend on the frames of perception of the next generation, it is a fact. The form of reception is a model which became the problem of representation (and it is a strong result of the influence of the popular culture) instead of reality, so the aesthetization instead of the ontology of the past. The epistemological challenge is modeled by the comparisons of the images; the Holocaust is mediatized by its images.

It is interesting how, in the research focused on the death and concentration camps, it became very popular to explore the camp brothels (places where women were forced to become the prostitutes). The representation of the Holocaust in popular culture reveals the archetypes of confrontation between Eros and Thanatos, even when they are represented in a naive and instrumental way. Thinking about what should be "interesting" it is important that the instrumental treating of the limits of this confrontation widen the limits of representing a human even at price of her/his dignity. Some texts of popular culture treat these limits fluently and instrumentally. Yosi Avni's novel Auntie Farhuma wasn't a whore, after all (hebr. Doda Farhuma Lo Haita Zona) provokes an interesting interpretation when the narrator describes two lovers. One of them wanted to make love listening to the music of the children of the Holocaust, the second one rejected this idea. Memory about the genocide as the aesthetical background for the lovers. If we agree with the statement, that still it is a problem in talking and representing the Holocaust, then we have to accept the fact that this issue is introduced into the relations of eradication of the thinking about the past, about real human pain and death (this eradication destroy common relationships), but that it also determined the styles of narration about the genocide by the frames of economic and political power. The Holocaust is not a set of spectacles. The com-

[7] http://www.wysokieobcasy.pl/wysokie-obcasy/ 1,53662,7879762,Nadzorczyni_z_SS.html?as=2\&start $\mathrm{sz}=\mathrm{x} .(2010.05 .16)$ 
modification of the Holocaust became the destruction of memory about people who were killed and who survived (and about their family's pain, fear, lost) - what means that instead of the knowledge about the genocide triggered the functioning of broken images.

Reading books about the representation of death in Western culture we can find there the diachronical, historical changes of the images of death: death as a skeleton, death as an illness, a woman and a man (with their putrid, rotting corpses), death as a lover, mother, but not death as a "me". And it is a form of paradox that on the one hand after World War Two death became an anonymous power of end, mass end, mass killing and destruction. It is the final result, the most radical influence of modernity. Death does not use a tool - it is a tool, the latest phase of using technology. On the other hand, in this context, death received also a human mask - not only from the perspective of victim, but also from the perspective of perpetrator. In one domain of popular culture, concentrating on the confrontation between Eros and Thanatos, the reduction of the reception of the Holocaust to that context showed that evil is possible in every mind and body. This form of temptation has also a continuity, for example when we think about Jonathan Littel's The Kindly Ones (2006) or about Welzer's description of human nature in the context of violence which is the result of the "activity" of rather normal than pathological minds (Welzer 15).

Eros and Thanatos imitate themselves in language - because of popular culture average receiver knows more names of perpetrators than victims (it is not only a hyperbole, because it reveals a lot of stereotypes and prejudices), but the way of gathering "knowledge" has a root in the phantasm where the source of pain is close to the source of pleasure. The question is: why?

The archetypical images of motherhood as the source of death were shown, written or told in the texts about children who were killed before their mother's eyes. Mother in this context is the source of life, but because of giving life she becomes the source of death (Guthke 223). How to show this - maybe unimaginable experience? What for?

The Holocaust - as the word refers (with the whole field of meanings) to the history, still, but it is also used in description of the ways of killing animals or becomes the metaphor of illness as the synonymous of AIDS. The Holocaust became a metaphor which is used in the political and social contexts. It functions as a fundamental figure in the poetics of biopolitical discourse. Regarding the perception of the illness by the terms which define it we try to understand our common source of fear. AIDS is like Hitler - what does it mean? "Hitler" even as a metonymy was not an illness; he was a man. AIDS is not a man but it is an illness. There are some elements which are common for both of the semantic fields of these terms; generally we can presume that it consists of the thinking about death, number of victims and about the scale of dying (killing by AIDS). Death or dying people are treated at the same level as people who were murdered - 
first level of manipulation. Second level of manipulation - refers to the understanding of the word victim (it is an abusing a historical meaning of being victim with the contemporary person who knows the risk because of making love without any protection; although the children infected by their mothers are victims, they are not the receivers of this social advertisement). Third level of manipulation - the number of victims, to understand the scale of people who died because of AIDS an average human must know the number of people who was killed during the period when Hitler ruled. This advertisement shows how the Holocaust is treated instrumentally even if it is now evoked explicitly. Again, by the confrontation of Eros and Thanatos the image of the Shoah is broken, where the figure of it is a woman shown in the typical, standardized for popular culture way. This message touches the archetypical frames: she is the source of life and a source of death, human body is inscribed in the tension between the physiology of pleasure and dying. This form of thinking is rooted in the context of instrumental reduction of the Holocaust to the tension between Eros and Thanatos. This confrontation is modeled by the frames of narration which unify understanding of some texts as a content of popular culture which are well known (idem per idem). To sum up, Hitler is not an illness and AIDS is not a man, even when we would like to treat these both figures as the metonymies we would repeat still the same mistake rooted in the misunderstanding determined by the meanings which function as the substitute by the analogies. The message of this advertising meant, more or less, the consequences of AIDS can be comparable to the consequences of genocide during the Second World War - this similarity is rooted in the metaphors we live by. It is a broken image of the Second World War. The man is the illness so an evil comes from patriarchal order. Woman as a figure of victim is shown a source of pleasure which because of lack of awareness dying feels pleasure.

We can find many other interpretations of this advertising which shows how kitsch constructs the comparison among the contexts, exploding by the manipulations of the perception of the facts. We can call it as a centripetal aspect of the reception of the Holocaust where it is treated as the metaphor for describing other social or cultural facts. The centrifugal aspect of reception is visible when we look for some analogies (also as a stylistic figures) to approximate the understanding the genocide. The process of the reception of the Holocaust in popular culture is not consistent, cohesive and unidirectional. It is a multinarrative, polisemiotic and transtextual, autopoietic and autoreferential process of textualization or even imagination of the Shoah determined by the systems of substitutions, equivalences and by the materialistic reduction the past to the set of goods for sale. The official discourses - for example by the museums full of interactive and multimedia or by movies or on official websites try to confront with the reduction of the Holocaust very often using 
codes which are recognizable in the mechanisms of perception in popular culture. This aporia is a challenge, a hard challenge when we think about fluent differences between periphery and centre of culture.

Popular culture is modeled by the system of signs which are rooted in language, other codes of communication, but also in the economic, political and media orientated fields. The domains shape the forms of axiological confrontations supplementing the frames of discourses. From the very beginning these discourses confront each other. The main character of the novel Aunti Farhuma... starts his narration telling that he was circumcised during the same day when Eichmann was hung - his life was connected with tradition, with the Shoah and with policy, the symbol of covenant became in this context the symbol of continuity in history after the Holocaust. One person has to deal with the collective (official and common) and with the individual history which started for him with the rite of circumcision and the shadow of the end of Eichmann. It is a symbolical beginning of the confrontation of identity with the evolutionary subsystems of popular culture. At the end of this confrontation there is an issue which can function as an approximation of the limits of improvement of the past. In this context an interpreter - because of the functioning of the mechanisms which constitute popular culture evolves to become a legislator of the reception of the Holocaust. For example the sender of some cultural text, some message which activates the social interactions, for example the author of film or generally an artists can evolve from being an interpreter to being a legislator. Artur Żmijewski's project 80064 shows that these limits are crossed when the artist "improve" work of perpetrators becoming a part of them.

Thinking about Auschwitz we must remember that it is not only the metonymy of the Holocaust, but that Auschwitz still refers to the concrete place where you can find still real traces of "rational", modern genocide. "Auschwitz" as the figure of narration should not erase Treblinka, Stumholf, Ravensbrück, Bełżec, and Majdanek, the forest in Kazimierz or in Rudzica! (Compare with the photo at the beginning of this article) When Auschwitz, as a part of Holocaust, will be reduced only to "Auschwitz" as a figure of narration which can be "useful" in popular culture, other places of death will be erased by the lack of memory, and the death of people will be destroyed. Real people (their faces and names) in real world were killed - it is the fact which cannot be forgotten or broken (Leociak 17). Telling about Auschwitz as a historical, social and symbolical fact means thinking about it as a metonymy of the whole genocide, but it is not the same. The history of the word "Holocaust" and hidden deeply within this word the misunderstanding - is also the history of reception of the genocide in culture and history of the reception of the texts which refer to the Jewish experience. 
Popular culture makes "new iron fences" "colorful" which means that the process of reception can become a process of reduction and then of forgetting. Broken images will not erase, to paraphrase the words of the poet, the meanings of the moss-grown matzevas: "In front of the old Jewish cemetery / swagger a large building of / hypermarket. / Moss-grown matzevas / look with disbelief at the colorful shopping gallery. / Among them grew a new iron / fence. / It is also colorful” (Kornhauser 65, trans. by M.K.).

Popular culture reflects the postmodern condition. Truth is mediated by the images of truths, history is mediated by the images of narrations, reality is mediated by the images of fiction, and cognition is mediated by the representations of the reality.

"The postmodernist concept of history is so oversaturated by the media, with its alternate truths and its instantaneous production of news (not to mention the virtual realities of cybernetic space), that, as Jean Baudrillard says, our reality is one of loss of reality. Even the difficulties of singling out an event, let alone speaking of the Holocaust as an event, especially in a hypermedia mass culture, makes any truth-statement about the nature and parameters of that event appear quite illusory and elusive. The discourse about the Holocaust has become yet another interface that shows victim and perpetrator to be interchangeable and makes it impossible to prove it happened" (Sicher 310, 311).

Contemporary culture, by using broken images created in mass media, shapes the substitutes of thorough knowledge. The results of it are not abstractive but real. This influence of culture can be treated as the substitute of knowledge defined for example by the educational contexts. The mechanisms of transmission of signs and texts use almost the same communicational and scientific tools such as: description, explanation, repetition, generalization, analogy, as well as parody, hyperbole, metonymy, irony, paraphrase, intertextuality, and the grotesque. Images became the exercises of the popular style, of the popular understanding which touch the limits of possibility in the reduction of the knowledge related to the Holocaust. These images function as the alternative source of knowledge about the genocide. Although these "limits" touch on not only the past, but also the present.

Auschwitz as an historical and social fact became "Auschwitz" as the metonymy of some facts, some issues, as a metaphor of representations and images which (can) reconstruct our notion of the Holocaust. Nostalgia is the key for approximation of the frames of this (not only stylistic) forms of representation. Modernity is shown as the context for the broken images and is used as the source of tools which create the paradoxes of objectivism.

The reception of the Holocaust in popular culture reveals on the one hand the limits of the thirst of knowledge and on the other hand a parade of ignorance (which is indeed stimulated and simulated). The frames of crossing the episteme focuses on playing with the 
past. In this context "past" refers to human, so "playing" could break, or even destroy the future. The president of Iran denies the Holocaust; the same person promotes the atom bomb. Learning from the past teaching for the future in the context of the genocide must imply truth.

Ankersmit, F. "Pamiętając Holocaust: żałoba i melancholia”. Ankersmit, F. Narracja, reprezentacja, doświadczenie. Studia $\mathrm{z}$ teorii historiografii. Ed. (and Introduction) E. Domańska. Trans. A. Ajschtet, A. Kubis, J. Regulska. Kraków, 2004.

Agamben, G. Co zostaje z Auschwitz. Archiwum i świadek (Homo sacer III) ("Remnants of Auschwitz: The Witness and the Archive"). Trans.

S. Królak. Warszawa, 2008.

Avni, Y. Ciotka Farhuma nie była dziwką. Trans. L. Kwiatkowski. Warszawa, 2007.

Certeau de, M. Wynaleźć codzienność. Sztuki działania. Trans. K. Thiel-Jańczuk. Kraków, 2008.

Cole, T. Selling the Holocaust. From Auschwitz to Schindler. How history is bought, packaged, and sold. New York, 2000.

Crepax, G. "Bianca. Historia nie z tej ziemi”. Crepax, Guido. Emmanuelle. Bianca. Trans. M. Fabjanowski. Miereki, 2009.

Gietka, E. “Jak opowiedzieć Auschwitz. Głosy”, Polityka, 5(2010).

Gorer, G. "Death, Grief, and Mourning in Contemporary Britain”. London, 1965. Quoted by Ostrowska, A. Śmierć w doświadczeniu jednostki i społeczeństwa. Warszawa, 1997.

Guthke, K.S. The Gender of Death. A cultural history in art and literature. Cambridge, 1999.

Hartman, G.H. The fateful question of culture. New York, 1997.

Jacobson, H. Wieczory kaluki. Trans. M. Świerkocki. Warszawa, 2008.

Jick, L.A. "The Holocaust: Its Use and Abuse within the American Public", Yad Vashem Studies, 14 (1981).

Kloch, Z. "Odmiany dyskursu. Semiotyka życia publicznego w Polsce po 1989 roku”. Wrocław, 2006.

Kornhauser, J. Origami. Kraków, 2007 (trans. by M. Kaźmierczak).

Kucia, M. Auschwitz jako fakt społeczny. Historia, współczesność i świadomość społeczna KL Auschwitz w Polsce. Kraków, 2005.

Leociak, J. "O nadużyciach w badanich nad doświadczeniem Zagłady". Zagłada Żydów. Studiai Materiały. Pismo Centrum Badań nad Zagładą Żydów IFiS PAN, nr 6 (2010).

Littell, J. Łaskawe. Trans. M. Kamińska-Maurugeon. Kraków, 2008.

Luther-Smith, A (ed.). "Delirium: A Guide to Italian Exploitation Cinema 19751979”. London 1979. Quoted by Petley, J.“Nazi Horrors: History, Myth, Sexploitation”, Horror Zone. Ed. Ian Conrich. I.B.Tauris, 2010. (text sent by prof. J. Petley).

Marcuse, H. Eros i cywilizacja. Trans. H. Jankowska, A. Pawelski. Warszawa, 1998.

Mintz, A. Popular Culture and the Shaping of Holocaust Memory in America. Seattle and London, 2001.

Novick, P. The Holocaust in American Life. Boston, New York, 2000.

Petley, J. "Nazi Horrors: History, Myth, Sexploitation". Horror Zone. Ed. Ian Conrich. I.B.Tauris, 2010.

Piotrowski, P. "Auschwitz versus Auschwitz". Piotrowski, P. Sztuka według polityki. Od melancholii do pasji, Kraków, 2007. 
Milchman, A., Rosenberg, A. Eksperymenty w myśleniu o Holocauście. Auschwitz, nowoczesność i filozofia. Trans. L. Krowicki, J. Szacki. Warszawa, 2003.

Rubenstein, R. The Cunning of History. The Holocaust and the American Future. New York, 1978.

Segev, T. The Seventh Million. The Israelis and the Holocaust. Trans. by H. Watzman. New York, 2000.

Sicher, E. "The Holocaust in the Postmodernist Era." Breaking Crystal. Writing and Memory after Auschwitz. Ed. Efraim Sicher. Illinois, 1998.

Sontag, S. Choroba jako metafora. AIDS i jego metafory. Trans. J. Anders. Warszawa, 1999.

Sontag, S. “Under the Sign of Saturn”. New York, 1981. Quoted by J. Petley, op.cit.

Struk, J. Holokaust w fotografiach. Interpretacje dowodów. Trans. M. Antosiewicz, Warszawa, 2007.

Turner, F. From counterculture to cyberculture: Stewart Brand, the Whole Earth Network, and the rise of digital utopianism. Chicago, London, 2006.

Vattimo, G. Koniec nowoczesności. Trans. M. Surma-Gawłowska. Introduction A. Zawadzki. Kraków, 2006.

Weizenbaum, J. Computer Power and Human Reason. From Judgment to Calculation. San Francisco, 1976.

Welzer, H. Sprawcy. Dlaczego zwykli ludzie dokonują masowych mordów. Trans. M. Kurkowska. Cooperation M. Christ. Warszawa, 2010.

Ziębińska-Witek, A. Holocaust. Problemy przedstawiania. Lublin, 2005.

Websites

www.wysokieobcasy.pl/wysokie-obcasy/1,53662,7879762,Nadzorczyni_z_SS. html (2010.05.16)

www.ssaufseherin.fora.pl (2010.12.21)

www.aids-is-a-mass-murder.com (2009.11.20)

www.dailymotion.pl/video/xadsq9_world-aids-day-2009-mass-murderer_ creation (2009.11.20)

www.stalags.com (2010.04.11) 